Article

\title{
Pleistocene Branchiopods (Cladocera, Anostraca) from Transbaikalian Siberia Demonstrate Morphological and Ecological Stasis
}

\author{
Anton A. Zharov ${ }^{1}$, Anna N. Neretina ${ }^{1}$, D. Christopher Rogers ${ }^{2}$, Svetlana A. Reshetova ${ }^{3,4}($, \\ Sofia M. Sinitsa ${ }^{4}$ and Alexey A. Kotov ${ }^{1, *(D)}$ \\ 1 A.N. Severtsov Institute of Ecology and Evolution, Leninsky Prt. 33, Moscow 119071, Russia; \\ antzhar.ipee@yandex.ru (A.A.Z.); neretina-anna@yandex.ru (A.N.N.) \\ 2 Kansas Biological Survey, and The Biodiversity Institute, The University of Kansas, Higuchi Hall, \\ 2101 Constant Avenue, Lawrence, KS 66047-3759, USA; branchiopod@gmail.com \\ 3 Vinogradov Institute of Geochemistry Siberian Branch Russian Academy of Sciences, Favorskogo Str. 1A, \\ Irkutsk 664033, Russia; srescht@mail.ru \\ 4 Institute of Natural Resources, Ecology and Cryology of the Siberian Branch of the Russian Academy of \\ Sciences, Nedorezov Str. 16A, Chita 672014, Russia; inrec.sbras@mail.ru \\ * Correspondence: alexey-a-kotov@yandex.ru
}

Received: 29 September 2020; Accepted: 28 October 2020; Published: 1 November 2020

\begin{abstract}
Pleistocene water bodies have been studied using the paleolimnological approach, which traces environmental changes using particular subfossils as ecological proxies, rather than analysis of the paleocommunities themselves. Within a given taphocoenosis, the presence and quantity of animals are related to environmental conditions rather than to community types where relationships between taxa are stabilized during their long-term co-occurrence and are (at least partially) more important than the particular environmental conditions at the time of deposition, which may have experienced significant seasonal and inter-seasonal variations. Here, we analyze Branchiopoda (Crustacea) of two paleolocalities in the Transbaikalian Region of Russia: Urtuy (MIS3) and Nozhiy (older than 1.5 million years). Cladocerans Daphnia (Ctenodaphnia) magna, D. (C.) similis, D. (Daphnia) pulex, Ceriodaphnia pulchella-reticulata, C. laticaudata, Simocephalus sp., Moina cf. brachiata, M. macropopa clade, Chydorus cf. sphaericus, Capmtocercus sp. and anostracans Branchinecta cf. paludosa, and Streptocephalus (Streptocephalus) sp. are found in two localities. With the exception of the last taxon, which now occurs in the southern Holarctic, all other taxa inhabit the Transbaikalian Region. Within Eurasia, the steppe zone has the greatest diversity of large branchiopods and a high diversity of some cladocerans, such as subgenus Daphnia (Ctenodaphnia) and Moina sp. Here we demonstrated that the branchiopod community in shallow steppe water bodies has been unchanged since at least the Pleistocene, demonstrating long-term morphological and ecological stasis.
\end{abstract}

Keywords: Crustacea; Branchiopoda; Eurasia; communities; Pleistocene; paleoecology

\section{Introduction}

The branchiopod crustaceans (fairy shrimps (Anostraca), tadpole shrimps (Notostraca), clam shrimps (Laevicaudata, Spinicaudata, Cyclestherida), and water fleas (Cladocera)) are well-known from various fossil strata, with the most ancient representatives (anostracans) reported from the Cambrian [1]. Anostracans, notostracans, and spinicaudatans form the earliest branchiopod communities in the Upper Devonian [2-4], whereas cladocerans are absent in the Devonian record. They may have been missed by paleontologists due to their small size and poor fossilization, and we do not know the exact time of their differentiation. Most Palaeozoic cladoceran fossil records are 
dubious [5]; regardless, the branchiopods are an ancient lineage. The first true cladocerans were found in Mesozoic strata, co-occurring with "large branchiopods" (anostracans, notostracans, and clam shrimp) [6-9], but their exact age of differentiation is unknown.

Branchiopod remains have been found in relatively young, Quaternary paleolocalities $[10,11]$ and there are numerous examples from the Early Holocene and Late Pleistocene [12-15]. The latter records are models for paleolimnologic environmental reconstructions based on subfossil remains. This method focuses on the autochthonous components of the taphocoenoses ("communities" of subfossil remains), in contrast to allochthonous components (such as pollen, spores, and terrestrial insects). Different branchiopods have different ecological preferences, and with large taphocoenosis data sets it is possible to determine aspects of the palaeoenvironment. Many cladoceran remains have been accurately identified to species [15-18]. In contrast, the large branchiopods are rarely used or even recorded in such studies $[10,19]$. They have potential paleo-ecological significance, but identification of their fossil remains (mainly mandibles, limbs, and resting eggs) is not sufficiently developed [20,21]. In addition, the large branchiopods prefer seasonally astatic aquatic habitats, whereas paleolimnological approaches have been primarily based on sediment cores from large lakes.

The Late Pleistocene has been studied using the paleolimnological approach, which traces environmental changes using particular subfossils as ecological proxies, rather than analysis of the paleo-communities themselves. Subfossil identification is conducted by experts in particular groups (i.e., cladocerans) frequently using methods that may destroy remains of other groups (such as boiling in potassium hydroxide [14,17]). Within a given taphocoenosis, presence and quantity are related to environmental conditions rather than to community types where relationships between taxa are stabilized during their long-term co-occurrence and are (at least partially) more important than the particular environmental conditions at the time of deposition, which may have experienced significant seasonal and inter-seasonal variations.

Neretina et al. [21] demonstrated that Late Pleistocene Beringia (less than 50 thousand years ago) freshwater branchiopod communities were at least partly non-analogous with any recent communities in that region, similar to the mammal ("Mammoth Fauna") and higher plant ("Mammoth tundra" = "tundra-steppe") groups, which also formed non-analogous communities [22,23]. Non-analogous fresh water communities also need to be further studied.

Here, we analyze an opposite situation in the Transbaikalian Region of Russia, where the branchiopod community in shallow steppe water bodies was unchanged at least during the Pleistocene, demonstrating long-term ecological stasis.

\section{Materials and Methods}

Numerous samples [24] were previously collected from two Pleistocene localities (Figure 1). They were preliminarily analyzed by the Institute of Natural Resources, Ecology and Cryology of the Siberian Branch of the Russian Academy of Sciences [25-27]. They provided material rich in branchiopod crustaceans.

The Urtuy paleolocality (coal mine "Urtuysky" near the town of Krasnokamensk, N50.17', E118.00 ${ }^{\circ}$ ) was located in the south-western portion of the Vostochno-Urulunguiskaya Depression. The site is a depression filled with dark grey, Middle-Late Pleistocene sediments of different ages, excavated through coal mining, with different concentrations of fossils [25]. Late Pleistocene-Early Holocene silts (120-8.2 KY) were rich with animal and plant remains [24]. We analyzed the samples taken at step III of the coal mine (see Figure 2 in Enikeev [25]), corresponding to MIS3. Radiocarbon dating of a mammoth tusk in a closer layer gave the age of 28,525 \pm 200 cal.y. Unfortunately, the locality was completely destroyed by mining, and more accurate dating is not possible. Palaeobotanical analysis led to the conclusion that the sediments were formed in a shallow lake surrounded by mainly steppe-meadow vegetation, with signs of climate aridity [26]. 


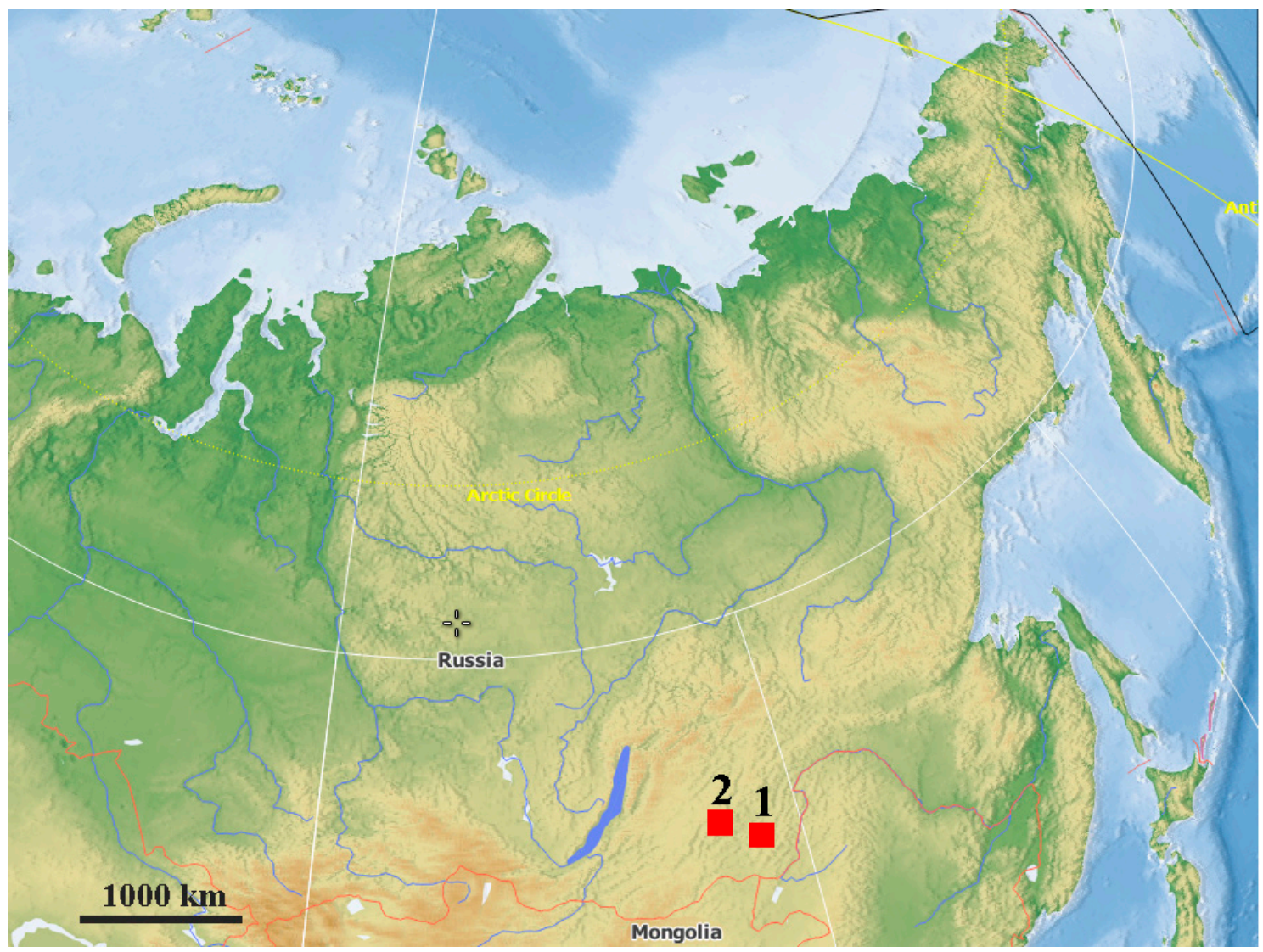

Figure 1. Map of north eastern Eurasia with geographic position of the two study sites: 1-Urtuy; 2-Nozhiy. The base maps are from the public domain atlas in the desktop app, Marble 2.2.20 (http://edu.kde.org/marble).

Nozhiy paleolocality (a ravine near Lake Nozhiy, N50.82 ${ }^{\circ}, \mathrm{E} 114.84^{\circ}$ ) is located in the Uldza-Toreyskaya Depression [24]. The section is part of the Tchasuchey Regional Series of the Transbaikalian Area [27], from the Lower Pleistocene. Its exact age is unknown; it is roughly estimated as Gelasian-Calambrian [28], with a lower boundary of 2.58 million years ago (Marine Isotope Stage 103 (MIS 103)) and upper boundary of 773 thousand years ago (MIS 19). The rare pollen of Tsuga Garrier (Pinaceae) was found in the same samples, but that gymnosperm was absent in Mongolia and the Trasbaikalian Area to ca. 1.5 MYA [29] and now occurs south of Transbaikalia. Therefore, our samples are probably older than 1.5 MYA. This section is represented by a sandy loam with clay lenses, containing numerous animal remains, including a large number of bones from the amphibians Strauchbufo raddei Strauch and Rana sp. [24]. The pollen and carpological analysis demonstrate that the sediments were formed in a large, shallow meso-eutropic lake with a developed macrophyte zone surrounded by steppe vegetation and some forest elements [24,26]. 

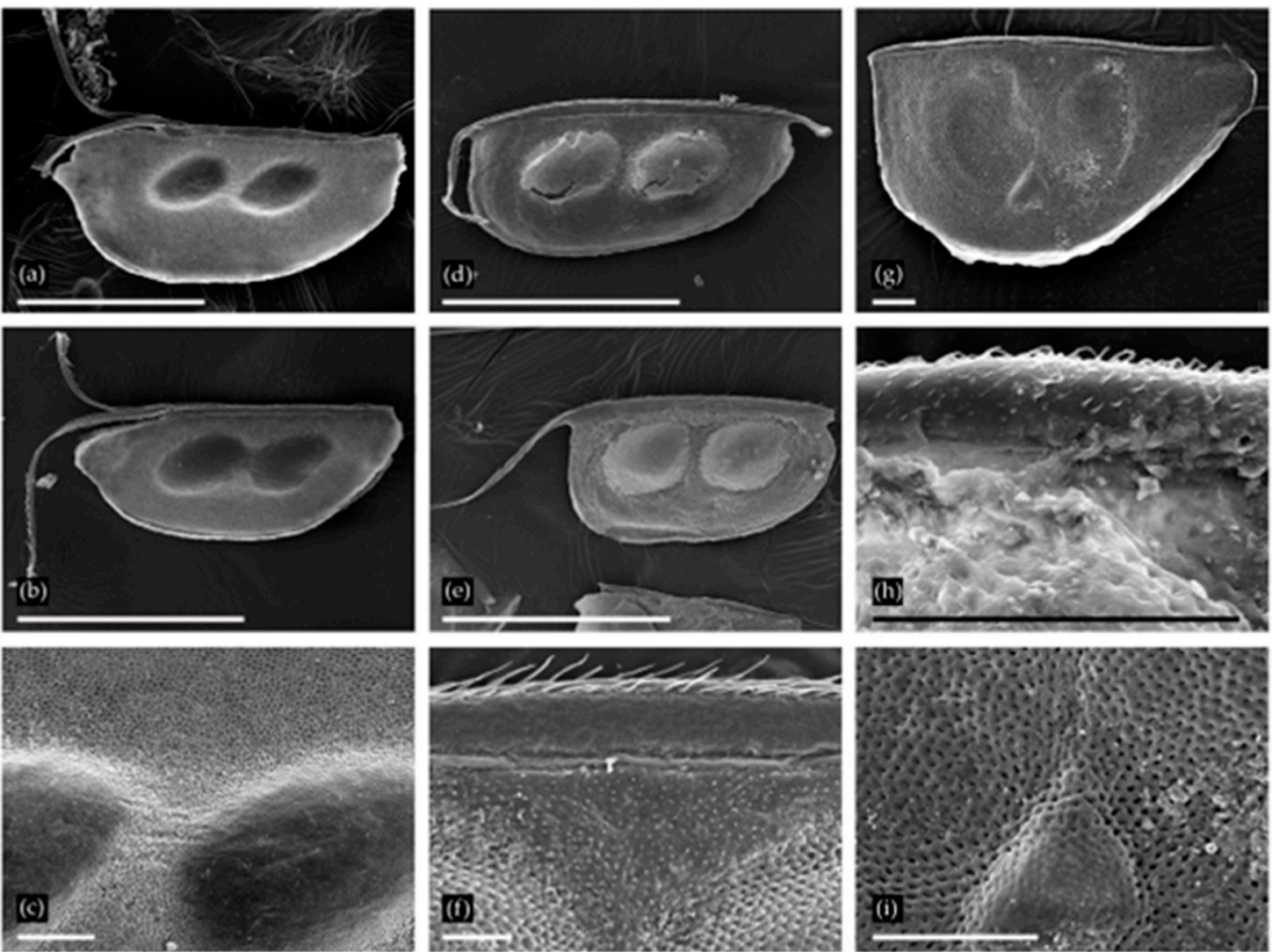

Figure 2. Ephippia of Daphnia from two localities: (a-c) D. (Ctenodaphnia) similis from Nozhiy, general view of two ephippia and sculpture in the region of egg loculi; (d-f) D. (Ctenodaphnia) magna from Urtuy, general view of two ephippia and sculpture in dorsal portion. (g-i) D. (Daphnia) cf. pulex from Urtuy, general view, armature of dorsal margin and sculpture in the region of egg loculi. Scale bars: $1 \mathrm{~mm}$ for a.b, $\mathrm{d}, \mathrm{G} ; 0.1 \mathrm{~mm}$ for $\mathrm{c}, \mathrm{f}, \mathrm{h}-\mathrm{i}$.

The samples from both localities were stored dried since collection. A quantity of $200 \mathrm{~g}$ of silt was analyzed from each locality. The samples of silt were manually subdivided into $1-3 \mathrm{~cm}^{3}$ fragments, triturated manually and weighed, and then placed in small net bags with $0.1 \mathrm{~mm}$ mesh size. The bags were soaked in clean water for $30 \mathrm{~min}$ to soften the contents. Then the bags were rinsed with tap water until the water was clear. The contents of each bag were placed in a small Petri dish and examined in clean water under a Leica MZ7.5 stereomicroscope (Leica Microsystems, Wetzlar, Germany), and all recognizable fragments were collected using a pipette or forceps, and transferred to $96 \%$ ethanol. Some branchiopod remains were preliminarily studied with a high-power Olympus CX-41 microscope (Olympus Corporation, Japan). A portion of crustacean remains was air dried, attached to stubs, coated with gold in a S150A Sputter Coater, and studied under a Vega TS5130MM scanning electron microscope (Tescan, Czech Republic). Individual specimens were identified using the relevant literature, reference collections, and personal experience.

The stubs for scanning electron microscopy (SEM) with extracted branchiopods are deposited in the collection of Borissiak Palaeontological Institute of Russian Academy of Sciences (Moscow), collection accession number: PIN RAN 5815. 


\section{Results}

\subsection{Cladocera}

Most cladoceran remains (especially in Utruy) (Table 1) belong to the genus Daphnia O.F. Müller (Figure 2).

Table 1. General list of branchiopod remains found in $200 \mathrm{~g}$ of silt from two Pleistocene localities.

\begin{tabular}{cccc}
\hline Taxon & Urtuy & Nozhiy & $\begin{array}{c}\text { Recent Steppe Water } \\
\text { Bodies in Transbaikalia } \\
\text { and Mongolia }\end{array}$ \\
\hline Cladocera & & & \\
\hline $\begin{array}{c}\text { Daphnia (Daphnia) pulex group } \\
\text { Daphnia (Ctenodaphnia) magna Straus }\end{array}$ & 675 & - & + \\
D. (C.) similis Claus & 10 & - & + \\
Ceriodaphni pulchella-reticulata & - & 24 & + \\
C. laticaudata P.E. Müller & 1 & - & + \\
Simocephalus sp. & 3 & - & + \\
Moina sp. & 6 & 3 & + \\
Chydorus cf. sphaericus & 1 & - & + \\
Alona s.lat. & 74 & - & + \\
\hline Anostraca & 1 & - & + \\
\hline Streptocephalus (Streptocephalus) sp. & 6 & 61 & + \\
Branchinecta cf. paludosa Müller & - & & + \\
\hline
\end{tabular}

Ephippia of the subgenus Daphnia (Ctenodaphnia) Dybowski et Grochowski provides us with valuable information. These species are rare in the forest zone, while common in temporary and large, shallow semipermanent and permanent lakes and ponds in arid regions [30]. The ephippium of $D$. (C.) similis (Figure $2 \mathrm{a}-\mathrm{c}$ ) is circular, with a deep linear cleft in the anteriodorsal portion, and it is sculptured with small tubercles [31,32]. Ephippia of D. (C.) magna (Figure 2d-f) are identified by the subrectangular shape (the anterior margin is usually almost straight) and scaliform sculpture [21]; These two species were found in Recent water bodies of the Transbaikalian Region [33-35] and the closest regions of Mongolia [36] (D. similis was reported as D. carinata, [32]). Furthermore, D. (C.) sinensis [32,34] is now present there, but was absent in Pleistocene samples.

The representatives of the Daphnia (Daphnia) pulex group (Figure 2g-i) could not be identified to species level with ephippium morphology [20]. This group consists of several species with different distributions [37] and ecological preferences [30], and to date, ephippia records have no indicator value. These species are found in Recent water bodies of the Transbaikalian Territory [34].

Ceriodaphnia Dana ephippia can be identified to species level [18]. A single deformed ephippium from Urtuy belonged to C. pulchella or C. reticulata (further identification impossible due to poor preservation) (Figure 3a,b). Most ephippia from Urtuy have a strong sculpture of rounded projections in the egg locula portion, characteristic of C. laticaudata P.E. Müller (Figure 3c,d). All Ceiodaphnia taxa are widely distributed in Northern Eurasia [38], including the Transbaikalian and Mongolian steppes [34,36]. Simocephalus Schödler ephippia (Figure 3e,f) cannot currently be identified to species level [39]. The species of Simocephalus are very common in various water bodies around the world [39].

Moina Baird ephippia were found to belong to two species groups. A single ephippium from Nozhiy has a single resting egg (Figure $3 \mathrm{~g}$ ). It was smoothed due to non-ideal preservation, but distinct reticulation is still visible on the egg chamber surface and on the valve margins. This type of ornamentation is characteristic of the Moina brachiata group [40,41]. Species of this group have wide ecological preferences, and inhabit a variety of Recent temporary water bodies [40,42]; they are recorded from the Transbaikalian Region and nearest regions of Mongolia [34-36,42]. 

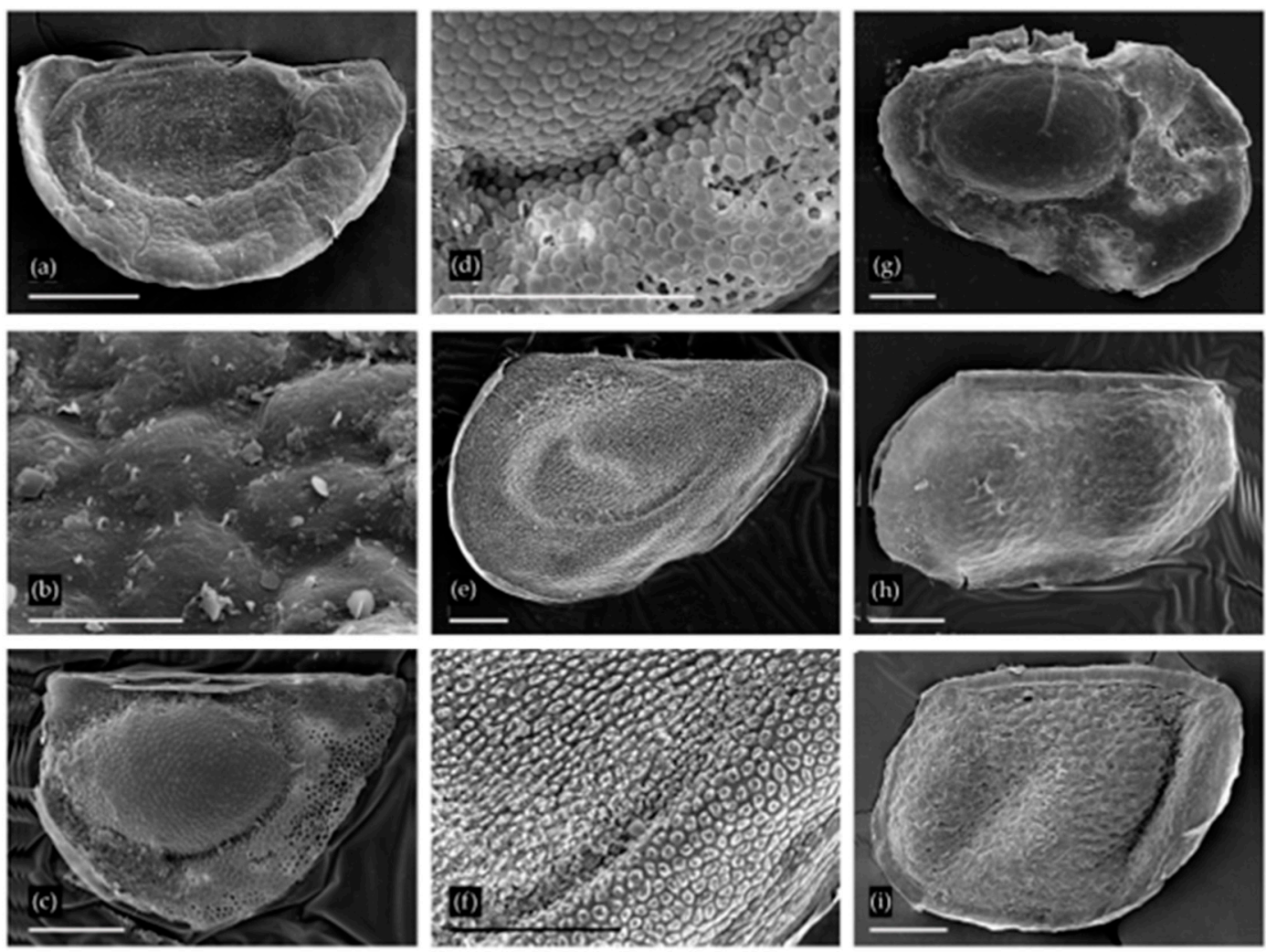

Figure 3. Ephippia of Daphniidae and Moinidae from two localities: (a,b) Ceriodaphnia pulchella-reticulata from Utruy, general view and sculpture in the region of egg locula; (c,d) Ceriodaphnia laticaudata from Urtuy, general view and sculpture at margin of egg locula; $(\mathbf{e}, \mathbf{f})$ Simocephalus sp. from Urtuy, general view and sculpture of ephippium; (g) Moina brachiata from Nozhiy; (h) Moina macrocopa group from Nozhiy;

(i) Moina macrocopa group from Urtuy. Scale bars: $0.1 \mathrm{~mm}$ for a, c-i; $0.01 \mathrm{~mm}$ for b.

Ephippia with two resting eggs from Nozhiy and Urtuy have a sculpture with more or less prominent reticulation (Figure 3h,i). These ephippia belong to the M. macrocopa clade according to Bekker et al. [42], including M. macrocopa (Straus), M. kaszabi Forró and M. lipini Smirnov. More accurate identification is impossible at this time. Some ephippia morphology studies using SEM have been conducted on the M. macrocopa species group [43]. All of these taxa may be found in the Recent Palaearctic eutropic temporary water bodies. Both of the first two taxa are found in the nearest regions of Mongolia [36,44].

It is most likely that the remains of Chydorus Leach (Figure 4a) belong to the C. sphaericus group. The members of this group are very common in all types of continental water bodies [45]. Species identifications are based solely on gamogenetic specimens [45,46]. Chydorus sphaericus populations are very common in the steppe water bodies of the Transbaikalian Region and adjacent Mongolia [33,34]. 

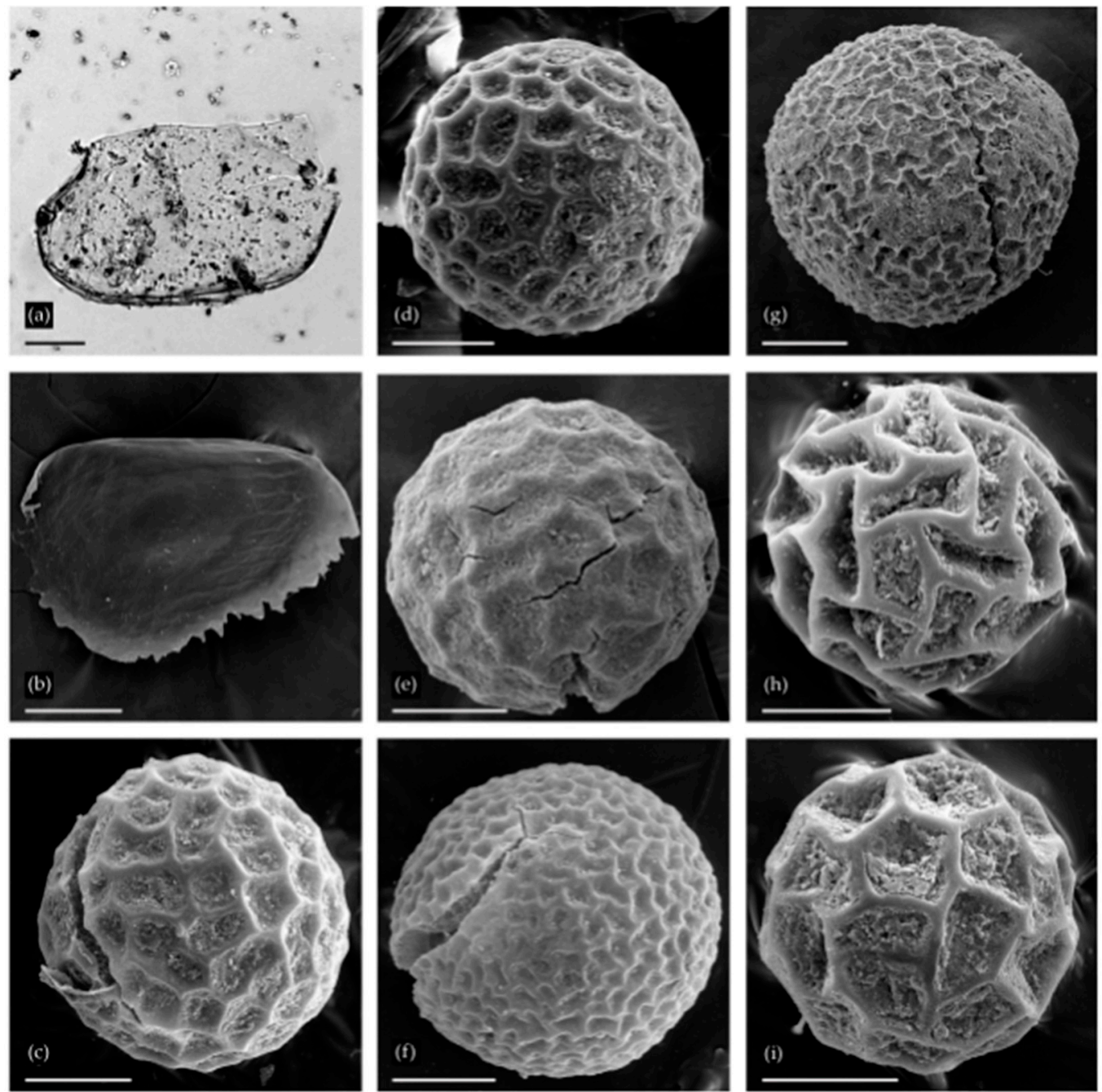

Figure 4. Remains of Cladocera $(\mathbf{a}, \mathbf{b})$ and resting eggs of Anostraca (c-i) from two localities: (a) Chydorus cf. sphaericus from Urtuy, valve; (b) Alona s. lat. from Urtuy, ephippium; (c-g) Branchinecta sp. from Nozhiy, resting eggs; (h,i) Streptocephalus sp. from Urtuy. Scale bars: $0.1 \mathrm{~mm}$.

A single Alona s. lat. ephippium (Aloninae) was found (Figure 4b); it is diagnosed by the small size, elongated shape, lack of sculpture on the egg locule, and weak linear sculpture on the posterioventral portion [17]. Representatives of this taxon are common in the Transbaikalian Region [47].

\subsection{Anostraca}

The eggs from Nozhiy belong to the genus Branchinecta Verrill (Branchinectidae). The eggs depicted in Figure 4c-e fit within the range of variation observed in the Holarctic B. paludosa (Müller), whereas the eggs in Figure 4f,g are fairly similar to Branchinecta ferox (Milne-Edwards), which is widespread in the Palaearctic. These eggs both match reasonably well to material in D. Christopher Rogers's collections, and with previously published images [48,49]. Both species are well known in Recent times throughout the region where the samples were collected.

Eggs from Urtuy (Figure 4h,i) appear to belong to the genus Streptocephalus s. str. The monobasic Streptocephalidae are widespread across Africa, tropical southern and southeastern Asia, and southern temperate North America and Europe [50,51]. In Asia, most species are found in the tropics and southwestern deserts [52,53], with one species ranging as far north as Guangxi Zhuang Autonomous Region and Yunnan Province, China [54]. Only one species in this genus (S. coloradensis Dodds, from North America) reaches northern latitudes equal to those at Urtuy [55]. Streptocephalus s. str. eggs 
are spherical and show a range of variation [56-58]. The material from Urtuy fits within the range of morphological variation found in other Asian species, specifically for S. dichotomus Baird (see [59], Figure2c,f,g), S. sirindhornae Sanoamuang, Murugan, Weekers, and Dumont (see [54], Figure 1e), S. shinsawbuae Shu, Rogers, Chen, \& Sanoamuang (see [53], Figure 4d), and S. simplex Gurney (see [60], Figures 1 and 2, and [61], Figure 2j).

Although it is not possible to deduce the specific identity at this time, the eggs appear to be most similar to S. sirindhornae, and may belong to that taxon, or another that is now extinct or unknown. The Urtuy site is roughly $3000 \mathrm{~km}$ north of the nearest known Streptocephalus populations, and those populations are S. sirindhornae in China and Myannmar [53,54].

\section{Discussion}

Most cladoceran ephippia and anostracan resting eggs found in our two Pleistocene localities belong to taxa inhabiting steppe water bodies of the Transbaikalian Region in Recent times, with the exception of Streptocephaus sp. It appears that the distribution pattern of this genus has changed similarly to the aforementioned gymnosperm Tsuga. The Anostraca [62], Daphnia (Ctenodaphnia) sp., and Moina sp. (and also Notostraca not found in our localities) form the dominant crustacean community complexes in this type of seasonally astatic water bodies [21,63]. We did not find any differences in the morphology of Transbaikalian Region branchiopod resting eggs between the Recent period and those from tens of thousands and even a million years ago. This observation confirms the opinion on morphological stasis in the cladoceran taxa $[64,65]$. The Anostraca and Notostraca are also classical stasis models $[3,4,65,66]$, and we demonstrate this once more.

Large branchiopods were nearly extinct in large water bodies during the Cenozoic, and used seasonally astatic and permanent saline water bodies as refugia (see review of Van Damme \& Kotov [5]). Kerfoot \& Lynch [67] assumed that the differentiation of bony fishes at the Palaeozoic/Mesozoic boundary drove the branchiopods into temporary waters. However, this idea ignores the fact that large branchiopods were present in many large water bodies during the Mesozoic and Early Cenzoic. For example, branchiopod remains are numerous in the Messel paleolake, which was a large Eocene permanent water body, where numerous fish also occurred [68]. In addition, there are examples of fish and large branchiopods coexisting today $[69,70]$. Extinction mechanisms of large branchiopods in large lakes are related to the formation of Recent type water bodies and cannot be easily determined at this time.

Recent temporary and permanent saline lakes in Eurasia are mainly associated with steppes and semideserts forming "The Eurasia Steppe Belt" [71]. Vekhov \& Vekhova [72] noted in the Eurasia forest zone that large branchiopods inhabit predominantly river floodplains, preferring the temporary vernal water bodies with neutral fresh water of snow melt and/or river origin unavailable for halophiles, whereas the larger watersheds are almost entirely lacking large branchiopods. Many shallow water bodies in forest zone watersheds are boggy and have a very low $\mathrm{pH}$, making them unavailable for most large branchiopods. It is most likely that northward forest expansion had a significantly negative impact on large branchiopods, similar to the large mammals of the "Mammoth Steppe" complex [73,74].

In contrast, in the steppe and semidesert zones branchiopods are common in both river valleys and watersheds under a wide range of salinity, from nearly distilled water to hypersaline lakes. It is difficult to define the steppe/semidesert water bodies, but they tend to be: (1) shallow, seasonally astatic or permanent, endorheic basins with highly variable hydroperiods and prolonged dry seasons; (2) under broad, seasonal gradients of temperature, salinity, etc. due to their shallowness and astatic fluctuations in filling and drying; (3) subject to a large $\mathrm{pH}$ range, dominated by alkaline water bodies; and (4) subject to the entire water column freezing in winter, but with little or no snow cover. These characteristics tend to be highly unattractive for many hydrobionts, including fish. Steppe and semidesert water bodies represent good branchiopod refugia, which is why they are extremely common there, with individual communities sometimes including many taxa. 
Within Eurasia, the steppe zone has the greatest diversity of large branchiopods $[63,72]$ and a high diversity of cladocerans, such as subgenus Daphnia (Ctenodaphnia) [36]. These branchiopods prefer neutral to alkaline, and not acidic, waters [75], although the specific distribution patterns are (at least for anostracans) directly related to soil geochemistry [76]. Branchiopods are not common in the forest zone where all large water bodies are populated by fish. Furthermore, the steppe water bodies form a distribution center for Moina sp., which has existed since the Mesozoic [6]. Here we have demonstrated that the steppe zone branchiopod fauna has remained unchanged during the Pleistocene.

Ecological stasis is generally characteristic of seasonally astatic water bodies: "temporary pools are probably the most permanent of all freshwater habitats" [65]. However, the ecological stasis in Transbaikalian shallow waters is related to the ecological stasis of the surrounding terrestrial communities. Steppe biomes are relatively old; modern-type steppe habitats were first recorded in Eurasia in the Eocene, and vast areas were covered by C4 grasslands in northern and southern hemispheres by the time of the Miocene/Pliocene boundary [77]. Since that time, the vegetation of the Transbaikalian Region was continuously represented as steppes (or savannahs) in contrast to more northern territories where the vegetation type was radically changed several times [78]. It is important to note that the unchanged vegetation type reflects relatively smooth climatic oscillations in the Transbaikalian Region compared to more northern territories [78]. We believe this is the main explanation of the observed ecological stasis in contrast to more northern territories where the branchiopod communities changed significantly at the Pleistocene/Holocene boundary, similarly to the terrestrial communities [21].

Author Contributions: Conceptualization, A.A.Z. and A.A.K.; methodology, A.A.Z.; software, A.A.K.; validation, A.A.Z., A.N.N., A.A.K., S.A.R. and D.C.R.; formal analysis, A.N.N., S.A.R., S.M.S.; investigation, S.A.R., S.M.S., A.A.Z. and A.N.N.; resources, S.A.R. and S.M.S.; data curation, A.Z.; writing-original draft preparation, A.Z., D.C.R. and A.A.K.; writing-review and editing, A.A.K. and D.C.R.; visualization, A.N.N.; supervision, A.A.K.; project administration, A.A.K.; funding acquisition, A.A.K. All authors have read and agreed to the published version of the manuscript.

Funding: The study of Branchiopoda is supported by the Russian Foundation for Basic Research (grant 18-04-00398a). SEM investigations were carried out at the Joint Usage Center "Instrumental methods in ecology" at the A.N. Severtsov Institute of Ecology and Evolution and supported by the Federal Governmental Task AAAA-A18-118042490059-5 for A.N. Severtsov Institute of Ecology and Evolution of Russian Academy of Sciences.

Acknowledgments: Many thanks to of the staff of Institute of Natural Resources, Ecology and Cryology of the Siberian Branch of the Russian Academy of Sciences for collecting of the samples studied here and to M.S, Boiko for his efforts to deposit the samples to PIN collection.

Conflicts of Interest: A.A.K. is Invited Editor of this special volume of "Water". Other authors declare no conflict of interest. The funders had no role in the design of the study; in the collection, analyses, or interpretation of data; in the writing of the manuscript, or in the decision to publish the results.

\section{References}

1. Harvey, T.H.P.; Vélez, M.I.; Butterfield, N.J. Exceptionally preserved crustaceans from western Canada reveal a cryptic Cambrian radiation. Proc. Natl. Acad. Sci. USA 2012, 109, 1589-1594. [CrossRef] [PubMed]

2. Lagebro, L.; Gueriau, P.; Hegna, T.A.; Rabet, N.; Butler, A.D.; Budd, G.E. The oldest notostracan (Upper Devonian Strud locality, Belgium). Palaeontology 2015, 58, 497-509. [CrossRef]

3. Gueriau, P.; Rabet, N.; Du Tien Hat, E. The Strud crustacean fauna (Late Devonian, Belgium): Updated review and palaeoecology of an early continental ecosystem. Earth Environ. Sci. Trans. R. Soc. Edinb. 2016, 107, 79-90. [CrossRef]

4. Gueriau, P.; Rabet, N.; Clément, G.; Lagebro, L.; Vannier, J.; Briggs, D.E.G.; Charbonnier, S.; Olive, S.; Béthoux, O. A 365-Million-Year-Old Freshwater Community Reveals Morphological and Ecological Stasis in Branchiopod Crustaceans. Curr. Biol. 2016, 26, 383-390. [CrossRef] [PubMed]

5. Van Damme, K.; Kotov, A.A. The fossil record of the Cladocera (Crustacea: Branchiopoda): Evidence and hypotheses. Earth Sci. Rev. 2016, 163, 162-189. [CrossRef] 
6. Smirnov, N.N. Mesozoic Anomopoda (Crustacea) from Mongolia. Zool. J. Linn. Soc. 1992, 104, 97-116. [CrossRef]

7. Kotov, A.A.; Korovchinsky, N.M. First record of fossil Mesozoic Ctenopoda (Crustacea, Cladocera). Zool. J. Linn. Soc. 2006, 146, 269-274. [CrossRef]

8. Kotov, A.A. Jurassic Cladocera (Crustacea, Branchiopoda) with a description of an extinct Mesozoic order. J. Nat. Hist. 2007, 41, 13-37. [CrossRef]

9. Kotov, A.A.; Taylor, D.J. Mesozoic fossils (145 Mya) suggest the antiquity of the subgenera of Daphnia and their coevolution with chaoborid predators. BMC Evol. Biol. 2011, 11, 129. [CrossRef]

10. Bennike, O. Palaeoecology of two lake basins from Disko, West Greenland. J. Quat. Sci. 1995, 10, $149-155$. [CrossRef]

11. Knecht, R.J.; Benner, J.S.; Rogers, D.C.; Ridge, J.C. Surculichnus bifurcauda n. igen., n. isp., a trace fossil from Late Pleistocene glaciolacustrine varves of the Connecticut River Valley, USA, attributed to notostracan crustaceans based on neoichnological experimentation. Palaeogeogr. Palaeoclimatol. Palaeoecol. 2009, 272, 232-239. [CrossRef]

12. Frey, D.G. The Ecological Significance of Cladoceran Remains in Lake Sediments. Ecology 1960, 41, 684-699. [CrossRef]

13. Polcyn, I. Application of Cladocera analysis in archaeology. Circaea 1996, 11, 41-48.

14. Korhola, A.; Rautio, M. Cladocera and other branchiopod crustaceans. In Tracking Environmental Change Using Lake Sediments; Springer: Dordrecht, The Netherlands, 2001; pp. 5-41.

15. Wojewódka, M.; Sinev, A.Y.; Zawisza, E.; Stańczak, J. A guide to the identification of subfossil chydorid Cladocera (Crustacea: Branchiopoda) from lake sediments of Central America and the Yucatan Peninsula, Mexico: Part II. J. Paleolimnol. 2020, 63, 37-64. [CrossRef]

16. Frey, D.G. The Taxonomic and Phylogenetic significance of the head pores of the Chydoridae (Cladoceha). Int. Rev. Gesamten Hydrobiol. Hydrogr. 1959, 44, 27-50. [CrossRef]

17. Szeroczyñska, K.; Sarmaja-Korjonen, K. Atlas of Subfossil Cladocera from Central and Northern Europe; Friends of the Lower Vistula Society: Świecie, Poland, 2007; ISBN 9788392491965.

18. Kotov, A.A.; Ibragimova, A.G.; Neretina, A.N. Identification of Ceriodaphnia Dana, 1853 (Crustacea: Cladocera) taxa from European Russia based on ephippial morphology. Zootaxa 2018, 4527, 105-123. [CrossRef] [PubMed]

19. Bos, D.G.; Cumming, B.F.; Smol, J.P. Cladocera and Anostraca from the Interior Plateau of British Columbia, Canada, as paleolimnological indicators of salinity and lake level. Hydrobiologia 1999, 392, 129-141. [CrossRef]

20. Kirillova, I.V.; van der Plicht, J.; Gubin, S.V.; Zanina, O.G.; Chernova, O.F.; Lapteva, E.G.; Trofimova, S.S.; Zinovyev, E.V.; Zharov, A.A.; Fadeeva, E.O.; et al. Taphonomic phenomenon of ancient hair from Glacial Beringia: Perspectives for palaeoecological reconstructions. Boreas 2016, 45, 455-469. [CrossRef]

21. Neretina, A.N.; Gololobova, M.A.; Neplyukhina, A.A.; Zharov, A.A.; Rogers, C.D.; Horne, D.J.; Protopopov, A.V.; Kotov, A.A. Crustacean remains from the Yuka mammoth raise questions about non-analogue freshwater communities in the Beringian region during the Pleistocene. Sci. Rep. 2020, 10, 859. [CrossRef]

22. Vereshchagin, N.K.; Baryshnikov, G.F. Paleoecology of the mammoth fauna in the Eurasian Arctic. In Paleoecology of Beringia; Elsevier: Amsterdam, The Netherlands, 1982; ISBN 9780123558602.

23. Guthrie, R.D. Frozen Fauna of the Mammoth Steppe. The Story of Blue Babe; University of Chicago Press: Chicago, IL, USA; London, UK, 1990; ISBN 978-0226311234.

24. Sinitsa, S.M.; Viliamova, E.S.; Yurgenson, G.A.; Reshetova, S.A.; Filenko, R.A. Geological Monuments of Transbaikalia: Cadastre of Stratigraphic and Paleontological Geological Natural Monuments; Nauka: Novosibirsk, Russia, 2014; ISBN 978-5-02-019120.

25. Enikeev, F.I. Quaternary lacustrine morpholithogenesis and development of hydrolaccolites (southern Transbaikalia). Geomorphology 2018, 1, 45-53. [CrossRef]

26. Karasev, E.V. Cenozoic fruits and seeds from the Urtuisky coal pit, Zabaikalie. In Proceedings of the 41st International Student Conference, Novosibirsk, Russia, 2003.

27. Karasev, V.V. Caenozoic of Transbaikalia; ChitaGeolSjomka: Chita, Russia, 2002. 
28. Gibbard, P.L. The Quaternary System/Period and its major subdivisions. Russ. Geol. Geophys. 2015, 56, 686-688. [CrossRef]

29. Bezrukova, E.V.; Kulagina, N.V.; Letunova, P.P.; Karabanov, E.V.; Wiliams, D.F.; Kuzmin, M.I.; Krapivina, S.M.; Vershinin, K.E.; Shestakova, O.N. Pliocene-quaternary vegetation and climate history of the Lake Baikal area, Eastern Siberia. In Long Continental Records from Lake Baikal; Kashiwaya, K., Ed.; Springer: Tokyo, Japan, 2003; pp. 111-135. ISBN 978-4-431-67981-3.

30. Benzie, J.A.H. The Genus Daphnia (including Daphniopsis) (Anomopoda. Daphniidae); Kenobi Productions: Ghent, Belgium, 2005; ISBN 90-5782-151-6.

31. Hudec, I. A comparison of populations from the Daphnia similis group (Cladocera: Daphniidae). In Biology of Cladocera; Kořínek, V., Frey, D.G., Eds.; Springer: Dordrecht, The Netherlands, 1991; pp. 9-22. ISBN 978-90-481-4101-2.

32. Popova, E.V.; Petrusek, A.; Kořínek, V.; Mergeay, J.; Bekker, E.I.; Karabanov, D.P.; Galimov, Y.R.; Neretina, T.V.; Taylor, D.J.; Kotov, A.A. Revision of the Old World Daphnia (Ctenodaphnia) similis group Cladocera: Daphniidae). Zootaxa 2016, 4161, 1-40. [CrossRef]

33. Krivenkova, I.F. Zooplankton of Lake Nozhiy. Estestv. Tekhnich. Nauki 2009, 5, 123-124.

34. Afonina, E.Y.; Tashlykova, N.A. Plankton community and the relationship with the environment in saline lakes of Onon-Torey plain, Northeastern Mongolia. Saudi J. Biol. Sci. 2018, 25, 399-408. [CrossRef] [PubMed]

35. Afonina, E.Y.; Tashlykova, N.A. Plankton of Saline Lakes in Southeastern Transbaikalia: Transformation and Environmental Factors. Contemp. Probl. Ecol. 2019, 12, 155-170. [CrossRef]

36. Alonso, M. Branchiopoda and Copepoda (Crustacea) in Mongolian saline lakes. Mongol. J. Biol. Sci. 2010, 8, 9-16.

37. Crease, T.J.; Omilian, A.R.; Costanzo, K.S.; Taylor, D.J. Transcontinental phylogeography of the Daphnia pulex species complex. PLoS ONE 2012, 7, e46620. [CrossRef]

38. Rogers, D.C.; Kotov, A.A.; Sinev, A.Y.; Glagolev, S.M.; Korovchinsky, N.M.; Smirnov, N.N.; Bekker, E.I. Chapter 16.2. Arthropoda: Class branchiopoda. In Thorp and Covich's Freshwater Invertebrates; Academic Press: London, UK, 2019; ISBN 9780123850249.

39. Orlova-Bienkowskaja, M.Y. Cladocera. Anomopoda: Daphniidae, Genus Simocephalus; Backhuys: Leiden, The Netherlands, 2001; ISBN 90-5782-090-0.

40. Smirnov, N.N. Macrothricidae and Moinidae of the World Fauna; Nauka: Moscow, Russia, 1976.

41. Alonso, M. Crustacea: Branchiopoda, Fauna Iberica; Consejo Superior de Investigaciones Cientificas: Madrid, Spain, 1996; ISBN 978-8400075712.

42. Bekker, E.I.; Karabanov, D.P.; Galimov, Y.R.; Haag, C.R.; Neretina, T.V.; Kotov, A.A. Phylogeography of Daphnia magna Straus (Crustacea: Cladocera) in Northern Eurasia: Evidence for a deep longitudinal split between mitochondrial lineages. PLoS ONE 2018, 13, e0194045. [CrossRef]

43. Montoliu-Elena, L.; Elías-Gutiérrez, M.; Silva-Briano, M. Moina macrocopa (Straus, 1820): A species complex of a common Cladocera, highlighted by morphology and DNA barcodes. Limnetica 2019, 38, 253-277.

44. Forró, L. Moina kaszabi sp.n. (Crustacea, Cladocera), its separation from M. belli Gurney by multivariative analyses. Acta Zool. Hungar. 1988, 34, 203-214.

45. Kotov, A.A.; Karabanov, D.P.; Bekker, E.I.; Neretina, T.V.; Taylor, D.J. Phylogeography of the Chydorus sphaericus Group (Cladocera: Chydoridae) in the Northern Palearctic. PLoS ONE 2016, 11, e0168711. [CrossRef] [PubMed]

46. Belyaeva, M.; Taylor, D.J. Cryptic species within the Chydorus sphaericus species complex (Crustacea: Cladocera) revealed by molecular markers and sexual stage morphology. Mol. Phylogenet. Evol. 2009, 50, 534-546. [CrossRef] [PubMed]

47. Smirnov, N.N. Chydoridae Fauni Mira; Nauka: Moscow, Russia, 1971.

48. Thiéry, A.; Brtek, J.; Gasc, C. Cyst morphology of European branchiopods (Crustacea: Anostraca, Notostraca, Spinicaudata, Laevicaudata). Bull. Mus. Nat. Hist. Natur. A. 1995, 17, 107-139.

49. Mura, G.; Thierry, A. Taxonomical significance of scanning electron microscopic morphology of the Euphyllopod's resting eggs from Morocco, Part, I. Anostraca. Vie Milieu 1986, 36, 125-131. 
50. Brendonck, L.; Rogers, D.C.; Olesen, J.; Weeks, S.; Hoeh, W.R. Global diversity of large branchiopods (Crustacea: Branchiopoda) in freshwater. Hydrobiologia 2008, 198, 167-176. [CrossRef]

51. Rogers, D.C. Branchiopoda (Anostraca, Notostraca, Laevicaudata, Spinicaudata, Cyclestherida). In Encyclopedia of Inland Waters; Elsevier: Amsterdam, The Netherlands, 2009; ISBN 9780123706263.

52. Rogers, D.C.; Padhye, S. A new species of Streptocephalus (Crustacea: Anostraca: Streptocephalidae) from the Western Ghats, India, with a key to the Asian species. Zootaxa 2014, 75-84. [CrossRef]

53. Shu, S.-S.; Rogers, D.C.; Chen, X.-Y.; Sanoamuang, L.-O. Streptocephalus diversity in Myanmar, with description of a new species (Branchiopoda, Anostraca). Zookeys 2018, 734, 1-12. [CrossRef]

54. Shu, S.; Maeda-Martinez, A.M.; Rogers, D.C.; Yang, J.; Chen, X. Morphological characterization of Streptocephalus sirindhornae (Branchiopoda: Anostraca) from South East Asia: First record of the Streptocephalidae from China. Zootaxa 2015, 3911, 447-450. [CrossRef]

55. Rogers, D.C. Two new cryptic anostracan (Branchiopoda: Streptocephalidae, Chirocephalidae) species. J. Crust. Biol. 2014, 34, 862-874. [CrossRef]

56. Mura, G. Pattern of Egg Shell Morphology in Thamnocephalids and Streptocephalids of the New World (Anostraca). Crustaceana 1992, 62, 300-311. [CrossRef]

57. Brendonck, L.; Coomans, A. Egg morphology in African Streptocephalidae (Crustacea: Branchiopoda: Anostraca) Part 1: North of Zambezi and Kunene rivers, and Madagascar. Arch. Hydrobiol. Suppl. 1994, 3, 335-356.

58. Brendonck, L.; Coomans, A. Egg morphology in African Streptocephalidae (Crustacea: Branchiopoda: Anostraca) Part 2: South of Zambezi and Kunene rivers. Arch. Hydrobiol. 1994, 3, 313-334.

59. Padhye, S.; Timms, B.; Ghate, H.V. Large branchiopod (Crustacea: Branchiopoda) egg morphology of Western Ghats, Maharashtra, India. Zootaxa 2016, 4079, 246-254. [CrossRef] [PubMed]

60. Munuswamy, N.; Subramoniam, T.; Mura, G. Ootaxonomic findings on anostracan eggs: A scanning electron microscopic study. Cytobios 1985, 42, 93-97.

61. Velu, C.S.; Munuswamy, N. Updated diagnoses for the Indian species of Streptocephalus (Crustacea: Branchiopoda: Anostraca). Zootaxa 2005, 1049, 33-48. [CrossRef]

62. Vekhov, N.V. Branchiopod crustaceans (Anostraca and Notostraca) of ephemeral water bodies of the steppe zone. Zool. Zh. 1989, 68, 241-250.

63. Yevdokimov, N.A.; Yermokhin, M.V. Crustaceans of zooplankton in temporary waterbodies of Saratov District on territory of different natural zones. Biol. Vnutr. Vod 2009, 1, 62-69.

64. Frey, D.G. Questions concerning cosmopolitanism in Cladocera. Arch. Hydrobiol. 1982, 93, 484-502.

65. Fryer, G. Structure and habits of living branchiopod crustaceans and their bearing on the interpretation of fossil forms. Earth Environ. Sci. Trans. R. Soc. Edinb. 1985, 76, 103-113. [CrossRef]

66. Fryer, G. Studies on the functional morphology and biology of the Notostraca (Crustacea: Branchiopoda). Phil. Trans. R. Soc. Lond. B 1988, 321, 27-124. [CrossRef]

67. Kerfoot, W.C.; Lynch, M. Branchiopod communities: Associations with planktivorous fish in space and time. In Predation. Direct and Indirect Impacts on Aquatic Communities; Academic Press: Hanover, Germany; London, UK, 1987; pp. 367-378.

68. Richter, G.; Baszio, S. Traces of a limnic food web in the Eocene Lake Messel-A preliminary report based on fish coprolite analyses. Palaeogeogr. Palaeoclimatol. Palaeoecol. 2001, 166, 345-368. [CrossRef]

69. Daborn, G.R. Occurrence of an arctic fairy shrimp Polyartemiella hazeni (Murdoch) 1884 (Crustacea: Anostraca) in Alberta and Yukon Territory. Can. J. Zool. 1976, 54, 2026-2028. [CrossRef]

70. Beladjal, L.; Dierckens, K.; Mertens, J. Dispersal of fairy shrimp Chirocephalus diaphanus (Branchiopoda: Anostraca) by the trout (Salmo trutta). J. Crust. Biol. 2007, 27, 71-73. [CrossRef]

71. Hurka, H.; Friesen, N.; Bernhardt, K.-G.; Neuffer, B.; Smirnov, S.V.; Shmakov, A.I.; Blattner, F.R. The Eurasian steppe belt: Status quo, origin and evolutionary history. Turczaninowia 2019, 22, 5-71. [CrossRef]

72. Vekhov, N.V.; Vekhova, T.P. Regional traits of the fauna of anostracans and notostracans of out-of-tundra territory of European Russia and Ukraine. Vetst. Zool. 1993, 5, 12-18. 
73. Barnes, I.; Shapiro, B.; Lister, A.; Kuznetsova, T.; Sher, A.; Guthrie, D.; Thomas, M.G. Genetic structure and extinction of the woolly mammoth, Mammuthus primigenius. Curr. Biol. 2007, 17, 1072-1075. [CrossRef]

74. Ǩičánková, V.P.; Horsák, M.; Hais, M.; Robovský, J.; Chytrý, M. Environmental correlates of the Late Quaternary regional extinctions of large and small Palaearctic mammals. Ecography 2018, 41, 516-527. [CrossRef]

75. Flössner, D. Die Haplopoda und Cladocera (ohne Bosminidae) Mitteleuropas; Backhuys: Leiden, The Netherlands, 2000.

76. Rogers, D.C. Anostracan (Crustacea: Branchiopoda) zoogeography II. Relating distribution to geochemical substrate properties in the USA. Zootaxa 2014, 3856, 1-49. [CrossRef]

77. Bredenkamp, G.J.; Spada, F.; Kazmierczak, E. On the origin of northern and southern hemisphere grasslands. Plant Ecol. 2002, 163, 209-229. [CrossRef]

78. Fenzel, B.; Pécsel, M.; Velichko, A.A. Atlas of Paleoclimates and Paleoenvironments of the Northern Hemisphere, Late Pleistocene-Holocene; Gustav Fischer Verlag: Budapest, Hungary; Stuttgart, Germany, 1992.

Publisher's Note: MDPI stays neutral with regard to jurisdictional claims in published maps and institutional affiliations.

(C) 2020 by the authors. Licensee MDPI, Basel, Switzerland. This article is an open access article distributed under the terms and conditions of the Creative Commons Attribution (CC BY) license (http://creativecommons.org/licenses/by/4.0/). 